\title{
Inclusive Innovation in Developed Countries: The Who, What, Why, and How
}

\author{
R. Sandra Schillo and Ryan M. Robinson
}

\author{
' ${ }^{\prime}$ There's something cooking and the lights are low. \\ 9 \\ Somebody's trying to save our mother earth. \\ I'm gonna help them to save it, \\ To sing it and bring it, \\ Singing: No no Keshagesh [greedy guts] \\ You can't do that no more, no more, no more, no more... \\ Buffy Sainte-Marie \\ Canadian singer-songwriter, visual artist, and social activist \\ In "No No Keshagesh"
}

\begin{abstract}
Although widely appreciated as an important driver of economic growth, innovation has also been established as a contributor to increasing economic and social inequalities. Such negative consequences are particularly obvious in the context of developing countries and extreme poverty, where innovation's contributions to inequalities are considered an issue of social and economic exclusion. In response, the concept of inclusive innovation has been developed to provide frameworks and action guidelines to measure and reduce the inequality-increasing effects of innovation. In developing countries, attention has only recently turned to the role of innovation in increasing inequalities, for example in the context of the degradation of employment in the transition from production to service industries. Although the focus of this early work is primarily on economic growth, innovation in developed countries also contributes to social exclusion, both of groups traditionally subject to social exclusion and new groups marginalized through arising innovations. This article summarizes the origins of the concept of inclusive innovation and proposes a four-dimensional framework for inclusive innovation in developed countries. Specifically, innovation needs to be inclusive in terms of people, activities, outcomes, and governance: i) individuals and groups participating in the innovation process at all levels; ii) the types of innovation activities considered; iii) the consideration of all positive and negative outcomes of innovation (including economic, social, and environmental); and iv) the governance of innovation systems. This framework is intended to guide policy development for inclusive innovation, as well as to encourage academics to investigate all dimensions of inclusive innovation in developed countries.
\end{abstract}

\section{Introduction}

Innovation, traditionally defined as the development of new goods, services, or processes, has long been an important driver of positive outcomes such as economic growth and societal well-being. However, a range of longer-term trends combined with the recent financial crisis and slow recovery have made it obvious that innovation also plays an important role in creat- ing negative outcomes, such as income inequalities (Aghion et al., 2015). In many developing countries, overall economic growth is no longer associated with socio-economic improvements for the poorest (Chataway et al., 2014). In developed countries, inequalities have increased to a level where they are socially and economically damaging (Stiglitz, 2012), giving rise to criticism of scientists and innovators as "remote elitists" (Long \& Blok, 2017). 


\title{
Inclusive Innovation in Developed Countries: The Who, What, Why, and How
}

\author{
R. Sandra Schillo and Ryan M. Robinson
}

Notionally, inclusive innovation has the potential to be a socially responsible endeavour (Fisher, 2017) - a means to address social and economic exclusion. This article discusses the concept of inclusive innovation and provides a framework of four key dimensions to consider in its implementation. The discussion of the framework's four dimensions - people, activities, outcomes, and governance - highlights that superficial implementation of inclusiveness concepts is unlikely to lead to the achievement of economic, social and environmental goals. Rather, true inclusiveness with economic, social, and environmental benefits will require a broader definition of innovation; structural and poststructural changes within the innovation landscape; reflexive and evolutionary policy design; and ample societal space for experimentation and exploration of different innovation narratives.

\section{Theoretical Precursors to Inclusive Innovation}

There is now broad consensus that innovation does not only serve economic growth and competitiveness, but that governments invest in innovation with a broad range of further objectives(Bozeman \& Sarewitz, 2011; Lindner et al., 2016; Mazzucato \& Semieniuk, 2017; Miller \& Neff, 2013; Schillo \& Kinder, 2017). This increased awareness of non-economic objectives is often framed in the context of "grand challenges" (Hicks, 2013; Kallerud et al., 2013) and has been applied extensively in policy development in Europe, the United States, and many other countries.

The arising expectations of innovation are immensely broad. At a high level, policy developers and citizens look to innovation to contribute to the solution of society's "grand challenges" (Kallerud et al., 2013), but there are also specific issues to which innovation is expected to make contributions, such as the introduction of low-carbon technologies (Andersen \& Johnson, 2015), agriculture and development (Joseph, 2014), and education. The emphasis on these expectations has increased substantially over the past 15 years (Hicks, 2016; Lindner et al., 2016), and researchers have suggested that it may lead to a new social contract of science and innovation (Owen et al., 2013) and may fundamentally transform both science and policy making (Kuhlmann \& Rip, 2014).

This broad societal and policy interest in the potential of innovation to contribute to society has been paralleled by several developments in the academic literature:
Public value mapping (Bozeman \& Sarewitz, 2011) is based on the theory of public value failure (Bozeman, 2002). This theory is a response to the prevalence of market failure motivations in public policy in general, and in science and innovation policy in particular. It is based on the assertion that governments should work in the public interest, and that market failure rationales do not provide sufficient motivation to address public values. An extensive body of literature has further developed this theory and approach, which has found broad resonance in the science policy community, and has recently also been brought into the discussion on responsible innovation (von Schomberg, 2014).

The quintuple helix (Carayannis \& Campbell, 2010; Carayannis et al., 2012) theory is similar in that it seeks to highlight considerations of societal importance, but it focuses specifically on the contributions of innovation to global warming and related environmental concerns. It builds on quadruple helix theory, which already integrates innovation into its social context, and sees "government, academia, industry, and civil society [...] as key actors promoting a democratic approach to innovation through which strategy development and decision-making are exposed to feedback from key stakeholders, resulting in socially accountable policies and practices" (Carayannis \& Campbell, 2012). As such, quintuple and n-tuple theory (Leydesdorff, 2012) integrate innovation within its societal and natural environments, and they highlight inclusiveness dimensions such as democratization of innovation and relevance to economic development (Carayannis \& Campbell, 2012).

Innovation for development and innovation for sustainable development emphasize society and the physical environment respectively. With regards to economic development, the potential of science and innovation to benefit developing countries has long been recognized, with policy programs in place since the 1950s and 60s (Brook et al., 2013) and an extensive literature on technology transfer from developed to developing countries (Reddy \& Zhao, 1990). Over time, such policies were viewed more critically. A key criticism relates to the conceptualization of developing countries simply as "recipients" of technology, and the related implementation of programs that limited local engagement to the application of existing technologies, rather than meaningful engagement in the innovation process. As a result, policies began to focus more on building scientific and technological capacity and infrastructure (Brook et al., 2013).

More recently, however, and in parallel to the consideration of grand challenges in the innovation context, an 


\title{
Inclusive Innovation in Developed Countries: The Who, What, Why, and How
}

\author{
R. Sandra Schillo and Ryan M. Robinson
}

emerging literature has renewed its focus on innovation for development - as compared to science and technology capacity and infrastructure. This emerging perspective considers innovation occurring in developing countries - using terms such as "frugal innovation" (Lehner \& Gausemeier, 2016; Zeschky et al., 2011), "reverse innovation" (Chataway et al., 2014), "Jugaad innovation", "bottom of the pyramid (BOP) innovation" (Hall et al., 2012; Prahalad, 2005), "Gandhian innovation", "empathetic innovation" and "pro-poor vs. fromthe-poor", "long-tail and long-tailoring innovation", "below-the-radar innovation" - and explicitly acknowledges social contexts characterized by resource constraints and insecurities (Pansera \& Martinez, 2017).

Innovation for sustainable development emerged as a literature stream in the 1990s in parallel to the increasing awareness of environmental damages and sustainability (Martin, 2016). From early publications onwards (Freeman, 1996; Kemp \& Soete, 1992; Rennings, 2000), this literature did not simply focus on product innovation leading to reduced environmental impacts, but rather considered the systemic implications of designing innovation for sustainability. This concern later found an expression in the literature on sustainability transitions (Geels, 2010) - a topic addressed by several researches who also are making key contributions to the inclusive innovation literature, such as Rip (e.g., Kuhlmann \& Rip, 2014) and Schot (e.g., Schot \& Steinmueller, 2016).

Technology assessment has its origin in the requirement of developing "an earlier awareness, an earlier warning, and an earlier understanding of what might be the social, economic, political, ethical and other consequences of the introduction of a new technology into the society or a substantial expansion of an existing technology" (Tran \& Daim, 2008), in particular for policy purposes in the United States. This stream of work was initiated in the late 1960s, and a range of tools was developed with varying foci, all of which involved foresight and a priori assessments. One particularly important stream of this research was developed in the context of health research to assess the potential health impacts of new technologies a priori. Another widely applied stream of research resulted in various forms of lifecycle assessments for environmental impacts. Initially, the consideration of stakeholders in technology assessment was limited to experts assessing the impact on various stakeholder groups (van Lente et al., 2017), but more recent methods of technology assessment emphasize the importance of including stakeholders in the assessment of technologies (participatory technology assessment: Sclove, 1995, 2012; Joss \& Bellucci (2002), and also in the creation of technologies themselves (constructive technology assessment: Schot \& Rip (1997).

Appropriate technologies is another concept that emphasizes the impacts of technologies. Building on the seminal work "Small is Beautiful" by Schumacher (1973), a flourishing community of practice and academic literature developed, focusing first on inventing more inclusive technologies, and then on implementing them. Pointing out that global research and development was highly concentrated in high-income economies, the appropriate technologies movement highlighted how the resulting technologies inadequately met the needs of the poor (Chataway et al., 2014). Although well-intentioned, the resulting technologies did not find broad uptake (Kaplinsky, 2011), and the appropriate technologies movement is generally considered a failure (Papaioannou, 2014), although its ideas have had a strong influence on many of the trends and streams of literature discussed here.

Responsible research and innovation (RRI) has emerged in the context of policy pressures on research and innovation to address societal concerns (Strand et al., 2015; van Lente et al., 2017; von Schomberg, 2012, also note the link with technology assessment: Delvenne, 2017; van Est, 2017; van Lente et al., 2017). RRI "is a transparent, interactive process by which societal actors and innovators become mutually responsive to each other with a view to the (ethical) acceptability, sustainability and societal desirability of the innovation process and its marketable products( in order to allow a proper embedding of scientific and technological advances in our society)" (von Schomberg, 2012).

The discourse on responsible innovation emerged particularly in the context of developments in nanoscience and nanotechnology research, and from an intent to consider societal implications and stakeholder interests early on. At that time, the difficulties surrounding genetically modified organisms were still recent and evolving, and the development of responsible innovation concepts aimed to ensure consideration of downstream effects early on in the process (Owen et al., 2013).

The inclusion of broad groups of stakeholders and potential consequences is central to RRI (Martin, 2013; Owen et al., 2012), and one framework explicitly contains "inclusion" as a dimension of RRI (Stilgoe et al., 2013). This work will be discussed in more detail in the following section. 


\title{
Inclusive Innovation in Developed Countries: The Who, What, Why, and How
}

\author{
R. Sandra Schillo and Ryan M. Robinson
}

In addition, broader trends in the innovation literature have recently challenged existing paradigms of innovation and have had far-reaching influence not only on how innovation is perceived. Open source software (von Hippel \& von Krogh, 2003), open innovation (Chesbrough, 2003), and open science (Partha \& David, 1994) hold the potential of increased collaboration and inclusiveness. However, experience shows that sustained societal benefits can only be achieved under all three paradigms if intellectual property is managed carefully, and successful collaborator communities have developed sophisticated standards and practices to systematically protect and reveal specific aspects of science and technologies. Especially the open source and open science movements often feature ambitions of increased inclusiveness both in the creation of innovation and in expanding access to innovation, but efforts to include socially diverse groups tend to require substantial efforts and are not very common to date.

User innovation, the democratization of innovation (von Hippel, 2005), and grassroots innovation (Fressoli et al., 2014; Smith et al., 2014) highlight the role of users as active participants in the innovation process. To round out this review, social innovation (Benneworth et al., 2014; Cajaiba-Santana, 2014) and entrepreneurship (Austin et al., 2006) emphasize the achievement of social outcomes and the integration of excluded groups within the innovation process, and "social innovation is specifically focused on the change of norms, regulations and cognitive frames with a view to improved social practices" (Ziegler, 2015).

\section{Inclusive Innovation}

The above description of relevant fields of research suggests that researchers approach the topic of inclusivity from a range of perspectives. In particular, inclusivity in terms of considering consequences of innovation is an important theme, and it emphasizes that innovation does not only lead to economic outcomes, but also to social and environmental outcomes. Within this general context of increased awareness of the social and environmental context of innovation, there are several developments that focus specifically on inclusive innovation or innovation for inclusion.

\section{Inclusive innovation proper}

The initial and most widely recognized definition of inclusive innovation refers to the economic development context, and specifically to poverty alleviation and bottom-of-the-pyramid considerations (Chataway et al., 2014). From this starting point, most recent definitions of inclusive innovation have extended the definition more broadly to include generally excluded groups of society:
"Inclusive innovation is the means by which new goods and services are developed for and by marginal groups (the poor, women, the disabled, ethnic minorities, etc)." (Foster \& Heeks, 2015)
"[T] he development and implementation of new ideas which aspire to create opportunities that enhance social and economic wellbeing for disenfranchised members of society." (George et al., 2012)

Using these definitions, the concept of inclusive innovation may seem limited to ensuring excluded groups of society are considered as customers, and maybe producers of innovations. However, the central tenet of this article is that such an interpretation would be overly simplistic and, based on prior experience and current statistics on exclusion, not likely to be effective. This recognition has given rise to the current academic and policy interest in inclusive innovation. The framework proposed below will outline four dimensions of inclusiveness and show that even the concept of including groups within the innovation process can take many forms. For example, inclusion can be conceptualized as consideration as potential customers, participation in the innovation process, and contribution to the evolution of innovation and societal systems (Foster \& Heeks, 2015; Fressoli et al., 2014).

\section{Innovation for inclusive growth}

Some authors use the terms "inclusive innovation" and "innovation for inclusive growth" interchangeably (George et al., 2012), especially where the context is economic development or bottom-of-the-pyramid considerations. However, many other authors make it clear that "inclusive growth" is a certain type of economic growth, which would consequently mean that inclusive innovation by this definition would be innovation targeted primarily at economic outcomes for certain demographics.

As we will argue in more detail below, retaining the broader consideration of social and environmental outcomes and inclusiveness along other dimensions is central to the concept of inclusive innovation. In that context, the consideration of innovation for inclusive growth does, however, provide an important delineation of circumstances under which the economic outcomes of innovation can be considered as inclusive. 


\section{Inclusive Innovation in Developed Countries: The Who, What, Why, and How}

\section{R. Sandra Schillo and Ryan M. Robinson}

Table 1 provides some of the definitions commonly used in the innovation for inclusive growth literature.

Klasen (2010) provides an extensive discussion of options to define inclusive growth. Key distinctions are whether only income is considered, or whether non-income dimensions are also included, and whether growth can be considered inclusive if it benefits all societal groups equally, or whether inclusiveness of growth necessarily required the reduction of inequalities.

The broad interest in innovation for inclusive growth by authors from several fields (Ali \& Son, 2007; Carayan-

Table 1. Definitions of inclusive growth

\begin{tabular}{ll} 
Definition & Source \\
\hline $\begin{array}{l}\text { "growth that not only creates new } \\
\text { economic opportunities, but also one } \\
\text { that ensures equal access to the } \\
\text { opportunities created for all segments of } \\
\text { society, particularly for the poor." }\end{array}$ & Ali \& Son (2007) \\
\hline $\begin{array}{l}\text { "economic growth that creates } \\
\text { opportunity for all segments of the } \\
\text { population and distributes the } \\
\text { dividends of increased prosperity, both } \\
\begin{array}{l}\text { in monetary and nonmonetary terms, } \\
\text { fairly across society" }\end{array}\end{array}$ & $\begin{array}{l}\text { \&lanes-Satorra } \\
\text { (OECD) }\end{array}$ \\
\hline
\end{tabular}

"More formally, an inclusive growth

Klasen (2010) episode requires

positive per capita income growth rates;

primary income [...] growth rates for predefined, disadvantaged groups [...] at least as high as growth rates for per capita incomes, indicating that such groups have been able to participate in the growth process at least proportionately; and expansions of non-income dimensions of well-being that exceed that average rate for pre-defined disadvantaged groups [...]; this would ensure that an income growth episode was disadvantage reducing." nis \& Rakhmatullin, 2014; George et al., 2012; Hall et al., 2012; Mazzucato, 2013; Planes-Satorra \& Paunov, 2017) has led to a slight blurring of definitions between inclusive innovation and innovation for inclusive growth. However, conceptually, innovation for inclusive growth is clearly anchored in the economic growth literature and as such only addresses a small subset of the issues raised by inclusive innovation.

\section{Definition within responsible research and innovation}

Research on RRI has developed several frameworks and methods to ensure and assess responsibility within science, technology, and innovation contexts. One framework in particular, that of Stilgoe and colleagues (2013), makes explicit reference to inclusiveness. The framework consists of four closely related dimensions that are important characteristics of responsive innovation. The first dimension, anticipation, requires ex-ante consideration of not only the potential of new technologies, but particularly also the risks new technologies may pose. Beyond technology assessments and forecasting, it also requires early involvement of the public to ensure pathways of technological development are aligned with societal expectations and needs. The second dimension, reflexivity, highlights that responsibility demands engaging critically with institutional practices within science, and with the value systems that underlie scientific and technological creation. The third dimension, inclusiveness, reflects the waning authority of expert, top-down science and policy development, and suggests that legitimacy needs to be established through involvement of broad stakeholder groups and the public. The last dimension, responsiveness, emphasises that responsible innovation requires a "capacity to change shape or direction in response to stakeholder and public values and changing circumstances" (Stilgoe et al., 2013).

This framework is also adopted in European Commission work on measurement of RRI (Strand et al., 2015), which also adopts the von Schomberg (2012) definition. Although they do not focus solely on inclusiveness, the measurement categories outlined by Strand and colleagues (2015) give some indication of the kinds of inclusiveness the European Commission is focused on. The categories are: public engagement, gender equality, science education, open access, ethics, governance, sustainability, and social justice/inclusion.

Clearly, these definitions extend the concept of inclusiveness beyond simply inclusiveness of economic out- 


\title{
Inclusive Innovation in Developed Countries: The Who, What, Why, and How
}

\author{
R. Sandra Schillo and Ryan M. Robinson
}

comes as the innovation for inclusive growth framework does. As we will argue below, the implications of consequent consideration of public engagement, gender equality, and sustainability - to name some of the key dimensions - suggest that more than economic growth needs to be considered.

This conceptualization of inclusive innovation - especially when it is assumed also to be anticipatory, reflexive, and responsive - addresses more of the concerns raised in the initial definition of inclusive innovation, but retains a narrow focus on technological innovation.

\section{Summary}

The preceding definitions of inclusive innovation are consistent in that they require the inclusion of previously excluded groups. The difference then lies in the way in which excluded groups are to be considered and to which extent the various dimensions of inclusion or exclusion are thematized in each model. Indeed, the literature places great emphasis on the nature of inclusion, highlighting the need of inclusion not simply as users or consumers of innovations, but also as producers, and designers of innovation (Chataway et al., 2014; Foster \& Heeks, 2015; Heeks et al., 2014; Pansera \& Martinez, 2017).

A second differentiating element is the type of innovation activities considered, and especially the role of technology in this regard. Much of the literature on inclusive innovation is deeply rooted in the science and technology literature, and as such has a strong bias towards good, service, or process innovations based on scientific or technological advances. However, numerous authors have challenged this narrow definition. Joseph (2014) argues that, in order to achieve the goal of inclusion, the focus needs to extend past the hightechnology sectors, which are traditionally considered highly innovative, to also consider innovation in labourintensive and labour-extensive sectors. Similarly, Foster and Heeks (2015) note that it should include sectors of particular importance to marginalized populations, such as health, education, and small-scale agriculture. However, to be truly inclusive, broader definitions are required. Paunov (2013) includes "not only R\&D-based innovation but also innovation based on practice rather than formal $\mathrm{R} \& \mathrm{D}$, and social and business innovations", and Dubé and colleagues (2014) include dimensions such as organizational, social, financial, and institutional innovation.

One of the drivers behind inclusive innovation is the social well-being of marginalized populations. Economic growth can be expected to alleviate a number of social issues, but history has shown that consideration of only economic outcome indicators is prone to lead to increasing inequalities and has created a strong motivation for the current trends towards more inclusive innovation. Thus, at a minimum, distributional effects of innovation need to be considered (Altenburg et al., 2009), but the more likely implication of inclusive innovation is that broader outcomes, such as quality of life (Bergeron et al., 2012), specific social outcomes, as well as environmental outcomes, need to be considered.

Finally, reflexivity with regards to the innovation process is a key emerging theme within the inclusive innovation literature. There is a clear call to consider innovating how we innovate (Dubé et al., 2014), even to the extent of challenging fundamental assumptions of the innovation process - such as the pursuit of consumption growth (Soete, 2013), competition between national systems of innovation (Schot \& Steinmueller, 2016), and even assumptions that remain to be challenged as a consequence of the inclusion of new actors in the innovation process (Kuhlmann \& Rip, 2014).

\section{Dimensions of Inclusive Innovation}

The summary above suggests that there are four dimensions - who, what, why, and how - along which innovation needs to be inclusive: people or groups of people included, the types of innovation activities included, a broad range of outcomes and benefits to be captured, and the governance mechanisms of innovation. In addition, the previous subsections highlight that inclusiveness cannot be superficial if it is expected to lead to positive impacts on inclusion - whether these are economic, social, or environmental outcomes.

\section{Who: People}

To answer the question of who should be included in innovation activities, two questions need to be answered: "Which groups of people should be included?" and "How should they be included?"

With regards to the first question - which groups to include - the literature refers to traditionally disadvantaged, marginalized, or excluded groups, although the main focus has been on the poor in developing countries, commonly referred to as the bottom of the pyramid (BOP) (Heeks et al., 2014). The definition of BOP is relatively consistently defined by incomes of $\$ 1.25 \mathrm{USD}$ per day or similar cut-offs (Chataway et al., 2014; Heeks et al., 2014). Translating the concept of inclusive innov- 


\title{
Inclusive Innovation in Developed Countries: The Who, What, Why, and How
}

\author{
R. Sandra Schillo and Ryan M. Robinson
}

ation to countries other than developing countries, authors often rely on the concept of social exclusion (Sen, 2000) to define marginalized or excluded groups. Commonly targeted groups for inclusive innovation interventions include women, youth, the disabled, ethnic minorities, and informal sector entrepreneurs (Heeks et al., 2014), or those defined by industrial or territorial boundaries (Planes-Satorra \& Paunov, 2017).

However, there is a risk that this approach will focus only on groups that historically faced social exclusion, and that it may ignore groups that are or will be affected by arising societal, technological, and broader innovation trends. A much-debated example demonstrating the importance of this is the pressure exerted by the introduction of artificial intelligence into the workplace. Innovations based on artificial intelligence have begun to replace jobs and are projected to substantially transform the labour landscape in coming years. The types of jobs affected will not be based on historical social exclusion, but rather on the potential of artificial intelligence to outperform humans. In fact, one of the earliest groups affected by artificial intelligence is financial traders on the stock market. Arguably, these were highly coveted jobs in the financial industry, with a high representation of individuals of high social inclusion status. Current projections further suggest that many of the jobs anticipated to become obsolete by this wave of innovation are well-paying, secure jobs, often currently held predominantly by men, such as jobs in the manufacturing sector, truck drivers, etc.

Thus, inclusiveness in the context of innovation and innovation policy needs to be both anticipatory and historically based, and ensure that not only historically excluded groups are considered, but that groups currently under pressure or predicted to be negatively affected by innovation trends are carefully considered in innovation conversations. It also needs to take into account that the means of social exclusion are changing, through widespread digitization and the use of big data analytics to define included and excluded populations.

With regards to the second question - how these groups should be included - Heeks and colleagues (2013) propose a framework with six levels. At the most basic level, intention, innovations address needs, wants, or problems of the focal group. The second level, consumption, refers to the focal group as users of an innovation, implying that the group can access and afford the innovation and has the motivation to adopt it. The third level, impact, sees an innovation as inclusive if it has positive impact on the focal group. Such impact is broadly defined and can include economic perspectives, well-being, capability increases, and others. Level four, process, sees inclusion of the group in the development of the innovation, with sub-levels distinguishing between being informed, being consulted, collaborating, being empowered, and controlling the development of innovation. Level five, structure, goes beyond individual innovations and focuses on the inclusiveness of institutions, organizations, and relations that make up innovation systems. Finally, level six, post-structure, acknowledges that innovation occurs within a frame of knowledge and discourse, which serves as the foundation of power distributions at the source of societal outcomes. Inclusive innovation in its most meaningful definition would occur in a context where diverse knowledge frameworks of all groups determine the structures, processes, and manifestations of innovation.

To illustrate these concepts, questions regarding the level of inclusion have been debated in the context of the inclusion of women in science and technology and more specifically in innovation. Nählinder and colleagues (2015) conducted a study on definitions of innovation and gender distribution of innovation characteristics. Notably, they found that women were less innovative than men using common definitions of innovation. However, when women's perspectives were integrated into the conceptual framing of innovation (i.e., they were included at level six, post-structure, in the model by Heeks and colleagues [2013]), such differences disappeared. Similar needs for post-structural inclusion can be expected with regards to any group to be included, which, of course, raises the difficult question of how to accomplish transitions to more inclusive frameworks without creating new dimensions of exclusion.

Another consideration from the gender context, which may hold true on a much broader level, is the consideration of mutual influences between existing innovation systems and newly included groups. At a time when women were increasingly involved in both consumption and production of science and technology, Franklin (1985) asked: "Will women change technology or will technology change women?". With regards to inclusion of economically disadvantaged groups, evidence (Chataway et al., 2014) suggests that inclusion of subsets of the bottom of the pyramid does not lead to systemically improved consideration of poverty. 


\title{
Inclusive Innovation in Developed Countries: The Who, What, Why, and How
}

\author{
R. Sandra Schillo and Ryan M. Robinson
}

Thus, we argue that inclusive innovation has to be anticipatory in its definition of groups to be included and open to engage at the structural or post-structural level of inclusion to be effective.

\section{What: Activities}

Current and past academic and policy conversations on inclusive innovation focus on science and technology-based innovations, and their commercialization pathways. Commonly referenced examples for inclusive innovation activities include "the provision of grants to researchers from disadvantaged groups, the deployment of programmes to popularise science and technology, the provision of micro-credit to entrepreneurs and the provision of grants to firms locating their R\&D activities in peripheral regions" (Planes-Satorra \& Paunov, 2017).

As the fundamental concern of inclusive innovation lies outside immediate economic growth considerations, it seems counterproductive to continue to only consider activities aiming at the commercialization of new products or processes as innovation. Even within the mainstream innovation literature, definitions of innovation are increasingly broad. One of the broader definitions has been proposed by the European Commission (1995): "innovation is taken as being a synonym for the successful production, assimilation and exploitation of novelty in the economic and social spheres".

Much earlier, in the early nineteenth century, Robert Owen aimed to address social concerns caused by the large mills in England's textile industry by introducing the organizational innovation of creating smaller mills that empowered the workforce and supported smaller communities (Chataway et al., 2014). Almost two centuries later, the combination of free and paid eye care offered in India through the Aravind Eye Hospital (www.aravind.org) also addresses social concerns, but we might consider this innovation a fundamental business model innovation - combining process, some product innovation, organizational, and financial innovations.

At this time, a promising framework by Dubé and colleagues (2014) refers to the combination of technological innovation, organizational innovation, social innovation, financial innovation, and institutional innovation as "convergent innovation", although future work would be useful to better position appropriate frameworks within the current proliferation of types of innovation.
Why: Outcomes

Many contributions in the inclusive innovation literature in the broad sense begin by outlining the transition of policy expectations towards innovation from narrowly focused contributions to economic growth, through inclusion of context- and field-specific outcomes, such as health, environmental, or social outcomes, to the current expectations of innovation policy to contribute to solving grand societal challenges (Kallerud et al., 2013; Kuhlmann \& Rip, 2014).

Capturing such outcomes of innovation is challenging (Martin, 2016) and has been subject to much academic research (refer to Strand et al. [2015] and Dubé et al. [2014] for initial references). Where health and environmental benefits are considered, there is also often a tendency to only capture positive impacts, leaving negative impacts among externalities not integrated into analysis and decision making.

In addition, the goal of inclusiveness complicates the consideration of outcomes even further, as the goal is often not only to improve overall health or social outcomes, but also to achieve greater equality in the distribution of outcomes. To date, distributional effects of both policies and specific innovations are rarely investigated (Altenburg et al., 2009), and should focus both on risks and benefits (Cozzens et al., 2009).

Finally, wholesome consideration of environmental impacts in particular makes it clear that the current paradigm of innovation is fundamentally tied to a "consumption growth path, which in its environmental impact and ecological footprint will be unsustainable in the developed world and increasingly so in the rapidly emerging country world" (Soete, 2013; also see Soete, 2010).

\section{How: Governance}

Most authors contributing to the literature on inclusive innovation acknowledge that inclusiveness is likely to have some implications on the institutions, structures, and mechanisms governing how innovation is implemented and conceptualized. Conceptualizations of these impacts range from the involvement of stakeholders in innovation policy, through changes in innovation processes and the need for institutional flexibility within innovation systems, to a vision for transformational changes to innovation systems.

The development of governance mechanisms allowing the inclusion of stakeholders in the innovation process 


\section{Inclusive Innovation in Developed Countries: The Who, What, Why, and How}

\section{R. Sandra Schillo and Ryan M. Robinson}

is one of the more obvious starting points. Issues considered in this regard are how to align stakeholder interests (Edler \& Fagerberg, 2017; Kemp \& Never, 2017), how to develop coordinated policy mixes (Kivimaa \& Kern, 2016; Rogge \& Reichardt, 2016), and how to facilitate alignment of policy mixes with stakeholder interests (Schillo et al., 2017). In many countries, mechanisms exist to include stakeholders for example through various advisory councils (Edler \& Fagerberg, 2017) and consultation processes. However, the stakeholders invited to join such councils or participate in consultations are typically representatives of key organizations along existing value chains. As such, this kind of inclusiveness tends to reinforce existing structures of inclusion and exclusion rather than offer opportunities for the inclusion of excluded groups.

A more fundamentally inclusive consideration would not only question such existing structures, but also the processes currently used to innovate. For example, an emerging literature challenges the importance of speed in the innovation process (Vogt, 2016; Woodhouse, 2016) and suggests that achieving societal outcomes will depend more on the "capacity to innovate in the way we innovate than on accelerating technology development" (Dubé et al., 2014).

Substantial changes to the way innovation occurs will also require institutional flexibility in the innovation system (Andersen \& Johnson, 2015) along the lines of the better governance principles and processes called for by the RRI literature (Owen et al., 2012; Stilgoe et al., 2013; von Schomberg, 2012), including "anticipation, participation, deliberation, transparency-to ensure that the process and direction of $R \& D$ and innovation better take into account societal preferences and concerns around ethics, sustainability" (Edler \& Fagerberg, 2017).

Perhaps most importantly, however, inclusiveness in the broad sense outlined in all four dimensions presented here is likely to imply transformative change within innovation systems (Schot \& Steinmueller, 2016). As Kuhlmann and Rip (2014) emphasize, inclusive innovation is not simply a funding priority within $R \& D$ policy, but rather "open-ended missions, and missions concerning the socio-economic system as a whole, even inducing (or requiring) system transformation" (Kuhlmann \& Rip, 2014).

\section{Conclusion}

This article has provided an overview of conceptualizations of inclusive innovation and presented a framework of four dimensions of inclusivity. It shows that inclusivity is not simply a matter of selling innovative products to socially excluded groups, or integrating small numbers of individuals from excluded groups within dominant innovation structures and processes. As previous experiences with appropriate technologies and BOP programs suggest, complementing the existing system with additional BOP programs will not solve the issue of poverty, nor can it address the globally increasing inequality. Without increased reflexivity, the current paradigm of innovation can be expected to reinforce current structures in many areas. To achieve any different outcomes, we need to develop the capacity to innovate how we innovate (Dubé et al., 2014).

It is clear that much remains to be discovered about inclusive innovation. This is not only the case due to a dearth of empirical data and even measurement frameworks, but also because inclusive innovation policy and practice require a fundamental openness to experimentation and adaptation. Perhaps most importantly, empirical and further theoretical development needs to involve groups and viewpoints not currently represented in the inclusive innovation literature. This literature has been heavily influenced by a relatively small group of primarily white men and some women - a limitation also affecting this article. From this perspective, the framework proposed in this article presents a step towards greater inclusiveness. Future theoretical or empirical academic work by more diverse groups of authors and practitioners may provide important new dimensions or reconceptualizations. In addition, implementation of this framework into policy and program development should be preceded by its critical evaluation by all relevant stakeholder groups and careful integration of feedback received.

Although the concept of holistic inclusive innovation has been juxtaposed to the current dominant innovation structure throughout this article, it is important to note that many of the drivers towards increased inclusivity are in place, and many examples exist of successful implementation of inclusive innovation initiatives or programs (Goel, 2011). Indications are that even if the transition towards inclusive innovation will neither be effortless nor automatic, inclusive innovation provides a plausible scenario for increased social and environmental sustainability on a global level. 


\section{Inclusive Innovation in Developed Countries: The Who, What, Why, and How}

\section{R. Sandra Schillo and Ryan M. Robinson}

\section{Acknowledgements}

The authors would like to thank Louise Earl and Jeff Kinder for insightful discussions on inclusive innovation.

\section{About the Authors}

R. Sandra Schillo is an Assistant Professor in Innovation and Entrepreneurship at the Telfer School of Management, University of Ottawa, Canada, and an affiliate of the Institute for Science, Society and Policy at the University of Ottawa. Prof. Schillo's research explores aspects of innovation and entrepreneurship that have policy and societal relevance. She has a strong background in technology transfer through her PhD (University of Kiel, Germany) and Master's level research (University of Karlsruhe, Germany). She also has practical experience in innovation management within the Canadian federal government and consulting on innovation and entrepreneurship policy issues.

Ryan M. Robinson is a Third Year Undergraduate student attending the University of Ottawa's Telfer School of Business Management in Ottawa, Canada. He was born and raised in Oshawa, Canada: a city with its history carved out by advances in technological innovation. Today, Ryan balances living in these two very different locales, both of which are writing the story of diversity and inclusion in Canada. Being continuously surrounded by innovative landscapes, Ryan plans continue to study the evolution of innovation in Canada following the completion of his degree in Finance.

\section{References}

Aghion, P., Akcigit, U., Bergeaud, A., Blundell, R., \& Hémous, D. 2015. Innovation and Top Income Inequality. National Bureau of Economic Research Working Paper Series. London: National Bureau of Economic Research.

http://dx.doi.org/10.3386/w21247

Ali, I., \& Son, H. H. 2007. Measuring Inclusive Growth. Asian Development Review, 24(1): 11-31.

Altenburg, T., Lundvall, B., Joseph, K., Chaminade, C., \& Vang, J. 2009. Building Inclusive Innovation Systems in Developing Countries: Challenges for IS Research. In B.-A. Lundvall, K. J. Joseph, C. Chaminade, \& J. Vang (Eds.), Handbook of Innovation Systems and Developing Countries: Building Domestic Capabilities in a Global Setting: 33-56. Cheltenham, UK: Edwar Elgar Publishing. http://dx.doi.org/10.4337/9781849803427

Andersen, A. D., \& Johnson, B. 2015. Low-Carbon Development and Inclusive Innovation Systems. Innovation and Development, 5(2): 279-296.

http://dx.doi.org/10.1080/2157930X.2015.1049849

Austin, J., Stevenson, H., \& Wei-Skillern, J. 2006. Social and Commercial Entrepreneurship: Same, Different, or Both? Entrepreneurship Theory and Practice, 30(1): 1-22. http://dx.doi.org/10.1111/j.1540-6520.2006.00107.x

Benneworth, P., Amanatidou, E., Edwards Schachter, M., \& Gulbrandsen, M. 2014. Social Innovation Futures: Beyond Policy Panacea and Conceptual Ambiguity. Enschede, Netherlands: European Forum for Studies of Policies for Research and Innovation.

Bergeron, M., de la Torre, M., \& Harasic, O. 2012. A New Scheme for Innovation: An Essay. Interciencia, 37(11): 857-860. http:/ /www.redalyc.org/articulo.oa?id=33925550010

Bozeman, B. 2002. Public-Value Failure: When Efficient Markets May Not Do. Public Administration Review, 62(2): 145-161. http://dx.doi.org/10.1111/0033-3352.00165

Bozeman, B., \& Sarewitz, D. 2011. Public Value Mapping and Science Policy Evaluation. Minerva, 49(1): 1-23. http://dx.doi.org/10.1007/s11024-011-9161-7

Brook, D., MacMaster, C., \& Singer, P. A. 2013. Innovation for Development. Ottawa: International Development Research Centre (IDRC). http://hdl.handle.net/10625/51577

Cajaiba-Santana, G. 2014. Social Innovation: Moving the Field Forward. A Conceptual Framework. Technological Forecasting and Social Change, 82: 42-51. https://doi.org/10.1016/j.techfore.2013.05.008

Carayannis, E. G., Barth, T. D., \& Campbell, D. F. J. 2012. The Quintuple Helix Innovation Model: Global Warming as a Challenge and Driver for Innovation. Journal of Innovation and Entrepreneurship, 1(1): 1-12. http://dx.doi.org/10.1186/2192-5372-1-2

Carayannis, E. G., \& Campbell, D. F. J. 2010. Triple Helix, Quadruple Helix and Quintuple Helix and How Do Knowledge, Innovation and the Environment Relate to Each Other? International Journal of Social Ecology and Sustainable Development, 1(1): 41-69. http://dx.doi.org/10.4018/jsesd.2010010105 


\section{Inclusive Innovation in Developed Countries: The Who, What, Why, and How}

\section{R. Sandra Schillo and Ryan M. Robinson}

Carayannis, E. G., \& Campbell, D. F. J. 2012. Mode 3 Knowledge Production in Quadruple Helix Innovation Systems: Springer. http://dx.doi.org/10.1007/978-1-4614-2062-0

Carayannis, E. G., \& Rakhmatullin, R. 2014. The Quadruple/Quintuple Innovation Helixes and Smart Specialisation Strategies for Sustainable and Inclusive Growth in Europe and Beyond. Journal of the Knowledge Economy, 5(2): 212-239.

http://dx.doi.org/10.1007/s13132-014-0185-8

Chataway, J., Hanlin, R., \& Kaplinsky, R. 2014. Inclusive Innovation: An Architecture for Policy Development. Innovation and Development, 4(1): 33-54.

http://dx.doi.org/10.1080/2157930X.2013.876800

Chesbrough, H. 2003. Open Innovation: The New Imperative for Creating and Profiting from Technology. Boston: Harvard Business School Press.

Cozzens, S. E., Kaplinsky, R., Lundvall, B., Joseph, K., Chaminade, C., \& Vang, J. 2009. Innovation, Poverty and Inequality. Cause, Coincidence, or Co-Evolution. In B.-Å. Lundvall, K. J. Joseph, C. Chaminade, \& J. Vang (Eds.), Handbook of Innovation Systems and Developing Countries: Building Domestic Capabilities in a Global Setting: 57-82. Cheltenham, UK: Edwar Elgar Publishing.

Delvenne, P. 2017. Responsible Research and Innovation as a Travesty of Technology Assessment? Journal of Responsible Innovation, May 2017: 1-11.

http://dx.doi.org/10.1080/23299460.2017.1328653

Dubé, L., Jha, S., Faber, A., Struben, J., London, T., Mohapatra, A., Drager, N., Joshi, P. K., \& McDermott, J. 2014. Convergent Innovation for Sustainable Economic Growth and Affordable Universal Health Care: Innovating the Way We Innovate. Annals of the New York Academy of Sciences, 1331(1): 119-141. http://dx.doi.org/10.1111/nyas.12548

Edler, J., \& Fagerberg, J. 2017. Innovation Policy: What, Why, and How. Oxford Review of Economic Policy, 33(1): 2-23. https://doi.org/10.1093/oxrep/grx001

European Commission. 1995. Green Paper on Innovation. Brussels: Office for Official Publications of the European Communities. http://aei.pitt.edu/id/eprint/1218

Fisher, E. 2017. Responsible Innovation in a Post-Truth Moment. Journal of Responsible Innovation, 4(1): 1-4. http://dx.doi.org/10.1080/23299460.2017.1330584

Foster, C., \& Heeks, R. 2015. Policies to Support Inclusive Innovation. Working Paper No. 61. Manchester, UK: Centre of Development Informatics, Institute for Development Policy and Management.

Franklin, U. M. 1985. Will Women Change Technology or Will Technology Change Women? Ottawa: Canadian Research Institute for the Advancement of Women.

Freeman, C. 1996. The Greening of Technology and Models of Innovation. Technological Forecasting and Social Change, 53(1): 27-39.

http://dx.doi.org/10.1016/0040-1625(96)00060-1

Fressoli, M., Arond, E., Abrol, D., Smith, A., Ely, A., \& Dias, R. 2014. When Grassroots Innovation Movements Encounter Mainstream Institutions: Implications for Models of Inclusive Innovation. Innovation and Development, 4(2): 277-292. http://dx.doi.org/10.1080/2157930X.2014.921354
Geels, F. W. 2010. Ontologies, Socio-Technical Transitions (To Sustainability), and the Multi-Level Perspective. Research Policy, 39(4): 495-510.

https://doi.org/10.1016/j.respol.2010.01.022

George, G., McGahan, A. M., \& Prabhu, J. 2012. Innovation for Inclusive Growth: Towards a Theoretical Framework and a Research Agenda. Journal of Management Studies, 49(4): 661-683. https://doi.org/10.1111/j.1467-6486.2012.01048.x

Goel, V. K. 2011. Instruments to Promote Inclusive Innovation: An Agenda for Inclusion and Growth. Paper presented at the Inclusive Innovation Workshop, Bangkok, March 4, 2011.

Hall, J., Matos, S., Sheehan, L., \& Silvestre, B. 2012. Entrepreneurship and Innovation at the Base of the Pyramid: A Recipe for Inclusive Growth or Social Exclusion? Journal of Management Studies, 49(4): 785-812.

https://doi.org/10.1111/j.1467-6486.2012.01044.x

Heeks, R., Amalia, M., Kintu, R., \& Shah, N. 2013. Inclusive Innovation: Definition, Conceptualisation and Future Research Priorities. Working Paper No. 53. Manchester, UK: Centre of Development Informatics, Institute for Development Policy and Management.

Heeks, R., Foster, C., \& Nugroho, Y. 2014. New Models of Inclusive Innovation for Development. Journal of Innovation and Development, 4(2): 175-185. http://dx.doi.org/10.1080/2157930X.2014.928982

Hicks, D. 2016. Grand Challenges in US Science Policy Attempt Policy Innovation. International Journal of Foresight and Innovation Policy, 11(1-3): 22-42. https://doi.org/10.1504/IJFIP.2016.078379

Joseph, K. 2014. Exploring Exclusion in Innovation Systems: Case of Plantation Agriculture in India. Innovation and Development, 4(1): 73-90. http://dx.doi.org/10.1080/2157930X.2014.890352

Joss, S., \& Bellucci, S. (Eds.) 2002. Participatory Technology Assessment. European Perspectives. London: Centre for the Study of Democracy.

Kallerud, E., Amanatidou, E., Upham, P., Nieminen, M., Klitkou, A., Olsen, D. S., Toivanen, M., Lima, M., Oksanen, J., \& Scordato, L. 2013. Dimensions of Research and Innovation Policies to Address Grand and Global Challenges. NIFU Working Paper 2013:13. Oslo: Nordic Institute for Studies of Innovation, Research and Education (NIFU). http://hdl.handle.net/11250/2358601

Kaplinsky, R. 2011. 'Bottom of the Pyramid Innovation'and Pro-Poor Growth. In Making Innovation Policy Work: Learning from Experimentation: 49-70. Paris: Organisation for Economic Cooperation and Development (OECD). http://dx.doi.org/10.1787/9789264185739-6-en

Kemp, R., \& Never, B. 2017. Green Transition, Industrial Policy, and Economic Development. Oxford Review of Economic Policy, 33(1): 66-84. https://doi.org/10.1093/oxrep/grw037

Kemp, R., \& Soete, L. 1992. The Greening of Technological Progress. Futures, 24(5): 437-457. http://dx.doi.org/10.1016/0016-3287(92)90015-8

Kivimaa, P., \& Kern, F. 2016. Creative Destruction or Mere Niche Support? Innovation Policy Mixes for Sustainability Transitions. Research Policy, 45(1): 205-217. https://doi.org/10.1016/j.respol.2015.09.008 


\section{Inclusive Innovation in Developed Countries: The Who, What, Why, and How}

\section{R. Sandra Schillo and Ryan M. Robinson}

Klasen, S. 2010. Measuring and Monitoring Inclusive Growth: Multiple Definitions, Open Questions, and Some Constructive Proposals. ADB Sustainable Development Working Paper Series No. 12. Manila, Philippines: Asian Development Bank (ADB).

Kuhlmann, S., \& Rip, A. 2014. The Challenge of Addressing Grand Challenges: A Think Piece on How Innovation Can Be Driven towards the" Grand Challenges" as Defined under the Prospective European Union Framework Programme Horizon 2020. Brussels: European Commission; European Research and Innovation Area Board (ERIAB).

Lehner, A.-C., \& Gausemeier, J. 2016. A Pattern-Based Approach to the Development of Frugal Innovations. Technology Innovation Management Review, 6(3): 13-21. http://timreview.ca/article/971

Leydesdorff, L. 2012. The Triple Helix, Quadruple Helix, ..., and an NTuple of Helices: Explanatory Models for Analyzing the Knowledge-Based Economy? Journal of the Knowledge Economy, 3(1): 25-35.

http://dx.doi.org/10.1007/s13132-011-0049-4

Lindner, R., Daimer, S., Beckert, B., Heyen, N., Koehler, J., Teufel, B., Warnke, P., \& Wydra, S. 2016. Addressing Directionality: Orientation Failure and the Systems of Innovation Heuristic. Towards Reflexive Governance: Fraunhofer ISI Discussion Papers Innovation Systems and Policy Analysis. Karlsruhe, Germany: Fraunhofer ISI.

Long, T. B., \& Blok, V. 2017. When the Going Gets Tough, the Tough Get Going: Towards a New-More Critical-Engagement with Responsible Research and Innovation in an Age of Trump, Brexit, and Wider Populism. Journal of Responsible Innovation, 4(1): 64-70.

http://dx.doi.org/10.1080/23299460.2017.1319036

Martin, B. R. 2013. Innovation Studies: An Emerging Agenda. In J. Fagerberg, B. R. Martin, \& E. S. Andersen (Eds.), Innovation Studies: Evolution and Future Challenges: 168-186. Oxford: Oxford University Press.

Martin, B. R. 2016. Twenty Challenges for Innovation Studies. Science and Public Policy, 43(3): 432-450.

https://doi.org/10.1093/scipol/scv077

Mazzucato, M. 2013. Smart and Inclusive Growth: Rethinking the State's Role and the Risk-Reward Relationship. In J. Fagerberg, B. R. Martin, \& E. S. Andersen (Eds.), Innovation Studies: Evolution and Future Challenges: 194-202. Oxford: Oxford University Press.

Mazzucato, M., \& Semieniuk, G. 2017. Public Financing of Innovation: New Questions. Oxford Review of Economic Policy, 33(1): 24-48.

http://dx.doi.org/10.1093/oxrep/grw036

Miller, T. R., \& Neff, M. W. 2013. De-Facto Science Policy in the Making: How Scientists Shape Science Policy and Why It Matters (or, Why STS and STP Scholars Should Socialize). Minerva, 51(3): 295-315.

http://dx.doi.org/10.1007/s11024-013-9234-x

Nählinder, J., Tillmar, M., \& Wigren, C. 2015. Towards a GenderAware Understanding of Innovation: A Three-Dimensional Route. International Journal of Gender and Entrepreneurship, 7(1): 66-86. https://doi.org/10.1108/IJGE-09-2012-0051

Owen, R., Macnaghten, P., \& Stilgoe, J. 2012. Responsible Research and Innovation: From Science in Society to Science for Society, With Society. Science and Public Policy, 39(6): 751-760. http://dx.doi.org/10.1093/scipol/scs093
Owen, R., Stilgoe, J., Macnaghten, P., Gorman, M., Fisher, E., \& Guston, D. 2013. A Framework for Responsible Innovation. In R. Owen, J. Bessant, \& M. Heintz (Eds.), Responsible Innovation: Managing the Responsible Emergence of Science and Innovation in Society: 27-50. Chichester, UK: John Wiley \& Sons, Ltd. https://doi.org/10.1002/9781118551424.ch2

Pansera, M., \& Martinez, F. 2017. Innovation for Development and Poverty Reduction: An Integrative Literature Review. Journal of Management Development, 36(1): 2-13. https://doi.org/10.1108/JMD-02-2015-0013

Papaioannou, T. 2014. How Inclusive Can Innovation and Development Be in the Twenty-First Century? Innovation and Development, 4(2): 187-202.

https://doi.org/10.1080/2157930X.2014.921355

Partha, D., \& David, P. A. 1994. Toward a New Economics of Science. Research Policy, 23(5): 487-521. https://doi.org/10.1016/0048-7333(94)01002-1

Paunov, C. 2013. Innovation and Inclusive Development: A Discussion of the Main Policy Issues. OECD Science, Technology and Industry Working Papers, No. 2013/01. Paris: Organisation for Economic Cooperation and Development (OECD). http://dx.doi.org/10.1787/5k4ddlrvsnjj-en

Planes-Satorra, S., \& Paunov, C. 2017. Inclusive Innovation Policies. Paris: Organisation for Economic Cooperation and Development (OECD). http://dx.doi.org/10.1787/a09a3a5d-en

Prahalad, C. K. 2005. The Fortune at the Bottom of the Pyramid: Eradicating Poverty through Profits. Vikalpa, 30(2): 149-153.

Reddy, N. M., \& Zhao, L. 1990. International Technology Transfer: A Review. Research Policy, 19(4): 285-307.

https://doi.org/10.1016/0048-7333(90)90015-X

Rennings, K. 2000. Redefining Innovation-Eco-Innovation Research and the Contribution from Ecological Economics. Ecological Economics, 32(2): 319-332.

https://doi.org/10.1016/S0921-8009(99)00112-3

Rogge, K. S., \& Reichardt, K. 2016. Policy Mixes for Sustainability Transitions: An Extended Concept and Framework for Analysis. Research Policy, 45(8): 1620-1635.

https://doi.org/10.1016/j.respol.2016.04.004

Schillo, R. S., Isabelle, D. A., \& Shakiba, A. 2017. Linking Advanced Biofuels Policies with Stakeholder Interests: A Method Building on Quality Function Deployment. Energy Policy, 100: 126-137. https://doi.org/10.1016/j.enpol.2016.09.056

Schillo, R. S., \& Kinder, J. S. 2017. Delivering on Societal Impacts through Open Innovation: A Framework for Government Laboratories. The Journal of Technology Transfer, 1-20. http://dx.doi.org/10.1007/s10961-016-9521-4

Schot, J., \& Rip, A. 1997. The Past and Future of Constructive Technology Assessment. Technological Forecasting and Social Change, 54(2-3): 251-268. https://doi.org/10.1016/S0040-1625(96)00180-1

Schot, J., \& Steinmueller, E. 2016. Framing Innovation Policy for Transformative Change: Innovation Policy 3.0. Brighton, UK: SPRU Science Policy Research Unit, University of Sussex.

Schumacher, E. F. 1973. Small is Beautiful: Economics as if People Mattered. London: Blond and Briggs. 


\section{Inclusive Innovation in Developed Countries: The Who, What, Why, and How}

\section{R. Sandra Schillo and Ryan M. Robinson}

Sclove, R. 1995. Democracy and Technology. New York: The Guilford Press.

Sclove, R. 2012. Reinventing Technology Assessment for the 21st Century. Washington, DC: Science and Technology Program, Woodrow Wilson International Center for Scholars (WWICS).

Sen, A. 2000. Social Exclusion: Concept, Application, and Scrutiny. Manila, Philippines: Asian Development Bank (ADB). http://hdl.handle.net/11540/2339

Smith, A., Fressoli, M., \& Thomas, H. 2014. Grassroots Innovation Movements: Challenges and Contributions. Journal of Cleaner Production, 63: 114-124.

https://doi.org/10.1016/j.jclepro.2012.12.025

Soete, L. 2010. From Science and Technology to Innovation for Development. African Technology Development Forum Journal, 7(3/4): 9-14.

http://atdforum.org/atdf-journal-industrial-policy/

Soete, L. 2013. Is Innovation Always Good. In J. Fagerberg, B. R. Martin, \& E. S. Andersen (Eds.), Innovation Studies Evolution \& Future Challenges: 134-144. Oxford: Oxford University Press.

Stiglitz, J. E. 2012. The Price of Inequality: How Today's Divided Society Endangers Our Future. New York: WW Norton \& Company.

Stilgoe, J., Owen, R., \& Macnaghten, P. 2013. Developing a Framework for Responsible Innovation. Research Policy, 42(9): 1568-1580.

https://doi.org/10.1016/j.respol.2013.05.008

Strand, R., Spaapen, J., Bauer, M. W., Hogan, E., Revuelta, G., \& Stagl, S. 2015. Indicators for Promoting and Monitoring Responsible Research and Innovation: Report from the Expert Group on Policy Indicators for Responsible Research and Innovation. Brussels: European Union Publications. https://doi.org/10.2777/9742

Tran, T. A., \& Daim, T. 2008. A Taxonomic Review of Methods and Tools Applied in Technology Assessment. Technological Forecasting and Social Change, 75(9): 1396-1405. https://doi.org/10.1016/j.techfore.2008.04.004

van Est, R. 2017. Responsible Innovation as a Source of Inspiration for Technology Assessment, and Vice Versa: The Common Challenge of Responsibility, Representation, Issue Identification, and Orientation. Journal of Responsible Innovation, 1-10. http://dx.doi.org/10.1080/23299460.2017.1328652 van Lente, H., Swierstra, T., \& Joly, P.-B. 2017. Responsible Innovation as a Critique of Technology Assessment. Journal of Responsible Innovation, 1-8. http://dx.doi.org/10.1080/23299460.2017.1326261

Vogt, T. 2016. How Fast Should We Innovate? Journal of Responsible Innovation, 3(3): 255-259. http://dx.doi.org/10.1080/23299460.2016.1258941

von Hippel, E. 2005. Democratizing Innovation: The Evolving Phenomenon of User Innovation. Journal für Betriebswirtschaft, 55(1): 63-78. https://doi.org/10.1007/s11301-004-0002-8

von Hippel, E., \& von Krogh, G. 2003. Open Source Software and the "Private-Collective" Innovation Model: Issues for Organization Science. Organization Science, 14(2): 209-223. https://doi.org/10.1287/orsc.14.2.209.14992

von Schomberg, R. 2012. Prospects for Technology Assessment in a Framework of Responsible Research and Innovation. In M. Dusseldorp \& R. Beecroft (Eds.), Technikfolgen abschätzen lehren: 39-61. Wiesbaden: Springer.

von Schomberg, R. 2014. The Quest for the 'Right' Impacts of Science and Technology: A Framework for Responsible Research and Innovation. In Responsible Innovation 1: 33-50. Netherlands: Springer.

Woodhouse, E. J. 2016. Slowing the Pace of Technological Change? Journal of Responsible Innovation, 3(3): 266-273. http://dx.doi.org/10.1080/23299460.2016.1259929

Zeschky, M., Widenmayer, B., \& Gassmann, O. 2011. Frugal Innovation in Emerging Markets. Research-Technology Management, 54(4): 38-45. https://doi.org/10.5437/08956308X5404007

Ziegler, R. 2015. Justice and Innovation-Towards Principles for Creating a Fair Space for Innovation. Journal of Responsible Innovation, 2(2): 184-200. http://dx.doi.org/10.1080/23299460.2015.1057796 